\title{
Human behavior inside and outside \\ bureaucracy: Lessons from psychology
}

DOI: $10.30636 /$ jbpa.11.13

\section{Asbjørn Sonne Nørgaard*}

\begin{abstract}
Both Herbert A. Simon and Anthony Downs borrowed heavily from psychology to develop more accurate theories of Administrative Behavior outside and Inside Bureaucracy: Simon, to explicate the cognitive shortcomings in human rationality and its implications; and Downs, to argue that public officials, like other human beings, vary in their psychological needs and motivations and, therefore, behave differently in similar situations. I examine how recent psychological research adds important nuances to the psychology of human decision-making and behavior and points in somewhat other directions than those taken by Simon and Downs. Cue-taking, fast and intuitive thinking, and emotions play a larger role in human judgment and decision-making than what Simon suggested with his notion of bounded rationality. Personality trait theory provides a more general and solid underpinning for understanding individual differences in behavior, both inside and outside bureaucracy, than the 'types of officials' that Downs discussed. I present an agenda for a behavioral public administration that takes key issues in cognitive psychology and personality psychology into account.
\end{abstract}

Keywords: Behavioral public administration, Bureaucracy, Judgement, Decision-making

$I$ $\mathrm{t}$ is surprising that a behavioral public admintration needs to be reinvented. Classics in our field had a strong focus on what is now seen to be the core elements of behavioral public administration: Individuals, whether managers, bureaucrats or citizens, and their behavior should be the analytical point of departure; and we should take important insights from psychology about human motivation, cognitive and affective processes of judgment and decision-making, and the non-rational aspects of human behavior seriously (Grimmelikhuijsen, Jilke, Leth Olsen, \& Tummers, 2017, p. 46; cf. Jilke, Van de Walle, \& Kim, 2016). I fully agree, but so did Herbert A. Simon with his focus on Administrative Behavior (1976 [1945]), and so did Anthony Downs with his keen appreciation of the fact that, what goes on Inside Bureaucracy (1967) is shaped by officials who have different psychological needs and motivations. Simon is an excellent point of departure when you want to understand how general psychological mechanisms shape administrative behavior, but cue-taking, fast and intuitive thinking and emotions probably play a larger role in human

\footnotetext{
* Department of Political Science and Public Management, The University of Southern Denmark

Address correspondence to Asbjørn Sonne Nørgaard at (ano@sam.sdu.dk)

Copyright: C 2018. The author licenses this article under the terms of the Creative Commons Attribution 4.0 International License.
}

judgment and decision-making than Simon suggested. Simon did not have much to say about individual differences, or variation in bureaucratic behavior. Downs, by contrast, focused extensively on how differences in individuals' motivations influence the behavior of "Specific Types of Officials" (1967, chapter IX). Still, Downs did not build on general psychological theory of individual differences. That may be the reason why Downs is widely referenced, but seems to be little used. Personality trait theory provides a more solid underpinning for understanding differences in bureaucratic behavior than Downs' notion of types of officials.

With a point of departure in the insights of Simon and Downs, the purpose of this article is to layout an, admittedly selective, agenda for the study of behavioral public administration that takes important insight from cognitive and personality psychology into account. The purpose is not to review this vast psychological literature, although I will reference key work that includes extensive references to the relevant literature. The agenda I propose clearly moves beyond Simon and Downs. For all their brilliance and ingenuity they could not foresee the knowledge and theoretical progress produced in various subfields of psychology since the time of their writing. This research pushes the behavioral public administration agenda further and raises new 
important questions about behavior inside and outside public bureaucracy.

\section{Herbert A. Simon - The Psychological Shortcomings of 'Administrative Man'}

Simon is probably most famous for his notion of 'bounded rationality' that eases the assumptions of strict rationality and highlights individuals' cognitive limitations. Human behavior, therefore, is " $i n$ tendedly rational, but only limited so" (Simon, 1976, p. xxviii). Individuals do not maximize, but merely 'satisfice' among the limited number of alternative decisions and routes of action they consider. In Simon's account the organization fills in many of the gaps and shortcomings in rationality, not least by providing goals and values to the individual and by focusing attention and supplying information. In this way individual behavior in administrative organizations ends up being "reasonably near to objective rationality" (Simon, 1976, p. 80). Simon makes clear in his 1976-introduction that he is not too fond of Freudian inspired social psychology that seems "to reduce all cognition to affect" (Simon, 1976, p. xxvii). Nonetheless, he duly recognizes that emotions, habits and non-rational elements play an important role in human judgment, decision-making and behavior. In particularly chapter five in Administrative Behavior on 'the psychology of administrative decisions' discusses the psychological aspects of human decision-making inside and outside administrative organizations. Still, if we take Simon's own observations and the recent research of others seriously I doubt that individual behavior necessarily, or even typically, is as 'reasonably rational' as Simon propagated.

Following Simon real behavior involves so "many elements of disconnectedness" that, viewed over time, behavior "exhibits a mosaic character" with shifts in attention, knowledge and even goals and values that are neither very accurate nor consistent (Simon, 1976, pp. 80, 82). Part of the problem of attention and knowledge has to do with memory and the accessibility of information and past judgments that have to be drawn upon to make a reasonably rational decision. Simon concludes that "human rationality relies heavily upon the psychological and artificial associational and indexing devices that make the store of memory accessible when it is needed" (Simon, 1976, p. 87), but he does not discuss the broader implications of these bottlenecks in working memory. 'Habits' is a partial remedy for the lack of thoughtful and conscious reflection. Without the need for conscious thinking habits guide behavior when triggered by situational stimuli. Somewhat heroically Simon seems to assume that habits are functional to the goals of the organization and rational to the individual, although he recognizes that habits tend to become automatic and that "it may require conscious attention to prevent the response from occurring even if changed circumstances have made it inappropriate" (Simon, 1976, p. 89).

To make rational judgments and decisions and escape inappropriate habits you have to be attentive to an issue, to spend time thinking about it, and make an effort to reach the right decision. As Simon correctly observes, this type of slow "hesitation-choice" pattern of decision-making "marks a relatively sophisticated level of behavior" psychologically speaking. Therefore, a simple and fast "stimulus-response pattern" of behavior is more common. The response to the stimulus may be partly reasoned and effortful, but Simon finds it to be "in large part habitual" (Simon, 1976, p. 91). Thus, for the habitual, stimulus-response type of behavior to be 'reasonably rational' within the context of the organization the stimuli must (a) primarily come from within the organization itself, and (b) be functional to the goals of the organization as well as the individual. These assumptions are not necessarily valid, and the non-rational aspects of individual behavior that Simon discusses may have quite different implications for administrative behavior than what he himself argued.

\section{Beyond Simon - General Psychological Influences on Administrative Behavior}

Since Simon's third edition of Administrative Behavior (1976) research in the psychology of how the mind works and how humans make judgments and decisions has developed enormously. As Andrei Shleifer observed in a thoughtful review of Daniel Kahneman's important book Thinking, Fast and Slow (2011), the problem is not only that "people get hard problems wrong, as bounded rationality would predict; they get utterly trivial problems wrong because they don't think about them in the right way" (Shleifer, 2012, p. 4). People may not satisfice and 'Take the Best' decision from a limited set of considered alternatives, although this is what people commonly do according to decision theorists who uphold Simon's original conjecture 
(Gigerenzer \& Goldstein, 1996). However, following the 'heuristic and biases' literature quite often people decide and judge fast and intuitively, e.g. using the available cues that come to mind or associating an event or a problem with a stereotypical 'class of similars' (Tversky \& Kahenman, 1974; Kahneman \& Tversky, 1996), and these "natural assessments" often err when measured against the yardstick of (bounded) rationality (Kahneman, 2000, pp. 682-683). Without claiming knowledge of all the important literature on human judgment and decision making, I think it is fair to say that few scholars are as optimistic as Simon regarding the prevalence of 'reasonably rational' decisions and behaviors among real people (see however Gigerenzer \& Goldstein, 1996; Cosmides \& Tooby, 1996); and bureaucrats, I assume, are a kind of real people too.

The most important insight in cognitive psychology since Simon, I will argue, is the fact that intuitions, emotions, habits and biases play a much larger role in human behavior than what Simon believed. I briefly discuss the implications of three related strands of literature that assign an important role to emotions and biases for human behavior inside and outside bureaucracy.

\section{Intuition and Fast Thinking}

For good reasons Simon does not couch his discussion of slow and fast thinking in terms of the more recent concepts of System 1 and System 2 thinking (Kahneman, 2011; cf. Stanovich \& West, 2000). System 1 is the evolved, 'normal' and less demanding form of thinking and making judgments and decisions. It is fast, intuitive, automatic and quite effortless, and builds on unconscious associational links in memory. However and contrary to Simon, we have little reason to assumes that the cues, heuristics and associations that individuals use primarily come from within the organization, e.g. in the form of standard operating procedures. Some heuristics such as reasoning in terms of likeness (or 'representativeness') may be quite universal (Kahneman \& Tversky, 1996; Kahneman, 2000), but the class of similar that comes to mind may emanate from outside the organization. Undoubtedly, some of the intuitions individuals unconsciously use have evolutionary roots (Cosmides \& Tooby, 1996; Petersen, 2015), some are culturally embedded (Nørgaard, 1996), and yet other are probably more idiosyncratically associated with the person's own history, personality traits and political orientations (McAdams \& Pals, 2006). System 2 is what we usually see as (cognitive) thinking; it is conscious, slow, effortful, deliberate, and requires focus and attention, but unfortunately it often does not guide human judgment and decisions.

Although bureaucrats are human beings, and therefore ipso facto prone to System 1 thinking, they also assume a (more or less) clearly defined role within an organization and quite a few are experts in what they are doing. There is some evidence suggesting that experts (e.g. List, 2003) are less inclined to use System 1 when making expertise-related decisions. Besides, clearly defined institutional roles and rules may also reduce the inclination to decide fast and automatic (March \& Olsen, 1989). The first issues that ought to be high on a behavioral public administration agenda are:

1. How much bureaucratic behavior is intuitive, automatic and cue-driven (System 1), rather than a result of effortful thinking (System 2)?

a. Do bureaucrats only/primarily take cues and use heuristics from within the organization?

b. Which types of administrative behaviors are most prone to intuitive thinking?

2. Under what conditions is bureaucratic behavior 'reasonably rational' (System 2)?

3. What is the role of professional training, role-demarcation, and management for the way bureaucrats make decisions (System 1 or 2)?

Whereas these questions are fairly general, the answers potentially may have quite dramatic consequences for theories and practice within public administration: If System 2 decisions are the exception to the rule, with what effect and by which mechanisms do organizational missions, management styles and leadership strategies influence bureaucratic behavior? If decisions typically are fast and associational, what is the behavioral effect of organizational strategies and plans that often include multiple, ambiguous and partially conflicting 
goals? Or on a practical level: Which management practices are most effective if intuitions and cuetaking shape bureaucratic decisions?

\section{Emotions and Affect}

The question is not if intuitions and emotions are more important for human decision-making than what Simon concluded, but how we are to understand the relation between fast, emotional and slow, cognitive processes of judgments and decisions (cf. Neuman, Marcus, Crigler, \& MacKuen, 2007; Schleifer, 2012; Brader \& Marcus, 2013). No doubt emotions color our judgments and decisions and sometimes make us err when compared to the standards of reasonable rationality (Johnson \& Tversky, 1983; cf. review by Blanchette $\&$ Richards, 2010).

In Appraisal Theory emotional valence is attached to an object as a result of how it has been interpreted and appraised (Lazarus, 1991). One can think of how Michael Lipsky's street-level bureaucrats categorize clients to cope with client demands and make caseloads manageable (1980). Others turn the sequence around and argue that cognitive appraisal follows preconscious emotional processes that link emotions to thoughts and intentions and ultimately behavior through associational pathways (Kunda, 1990; Taber \& Lodge, 2016). In that sense all cognition is 'hot' rather than cold, conscious and calculating; and all reasoning and judgment will be biased and motivated by other concerns than to get it right. To continue the example with street-level bureaucrats, in this line of reasoning sympathies and antipathies come before categorization and behavior. Still, whether cognitive appraisals or emotional associations come first seems somewhat irrelevant if it happens at a preconscious level and if these preconscious processes influence judgments and decisions. Some neuroscientists argue that the two processes are intertwined (see Brader \& Marcus, 2013).

Individuals in a positive mood tend to estimate a higher likelihood of positive events than those who are in a negative mood, and vice versa (Blanchette \& Richards, 2010). But not only emotional valence, also the type of emotion matters (Angie, Connelly, Waples, \& Kligyte, 2011). Anxiety and fear tend to increase risk estimates and make people more risk-averse whereas anger reduces risk estimates and makes people more prone to take risks (Lerner \& Keltner, 2000). Evidence suggests that in the face of perceived threat anger is associated with a preference for swift and punitive policies whereas anxiety is associated with hesitant and thoughtful consideration before taking action (Huddy, Feldman, Taber, \& Lahav, 2005; cf. Schwarz, 2000). Following Affective Intelligence Theory different types of emotions trigger different ways of thinking (Marcus, Neuman, \& MacKuen, 2000). People who feel enthusiastic and thrilled act on their dispositions without much thinking, i.e. fast and intuitive akin to System 1. When individuals become anxious and uneasy about something, they activate their 'surveillance system', engage in slow, effortful thinking, and make 'reasonably rational', deliberate decisions (System 2). Much like enthusiasm, anger seems to be associated with dispositional and fast judgments and decisions rather than effortful, deliberate decisions (Huddy et al., 2005; Huddy, Feldman, \& Cassese, 2007).

Emotions play an important role for political judgment and behavior in the mass public. For instance, during elections enthusiastic citizens become more interested and engaged in politics, but not very critical and vigilant; whereas anxious citizens become more alert and attentive towards the candidates and their messages, but not necessarily more engaged and politically motivated (Marcus et al., 2000; Brader, 2006).

The interplay of emotions and cognition in human judgment and decision-making is an important topic that has been scrutinized extensively in cognitive and organizational psychology and in management studies, but so far it has received scant attention within public administration. Bureaucratic rules are designed to squeeze out emotions and hence potential biases in decision-making. The ideal-type of Weberian bureaucracy is premised on this (Weber, 1920), but many public services and interventions are organized much less rigidly than a classic bureaucracy because decisions need to be flexible and rely on discretionary (expert) judgment, especially when interventionist policies regulate complex behaviors (Rothstein, 1998). In these situations, research shows that cognitive constructs like perceptions, endorsement and knowledge of policy substantially influence street-level bureaucrats' compliance with rules and behavior towards clients (e.g. Brehm \& Gates, 1997; May \& Winter, 2009). How emotions towards bureaucratic superiors and clients influence the decisions made by street-level bureaucrats is not studied. Following the literature we should expect very different effects from enthusiasm, anxiety and anger. 
The extent to which emotions influence bureaucratic decisions in different contexts and under different task conditions raises a number of issues. The most important include:

4. To what extent is bureaucratic behavior shaped by emotions?

a. Does enthusiasm increase motivation, but not vigilance and thoughtfulness?

b. Does anxiety increase critical thinking, but not loyalty and goal-congruence?

c. How do rules and task conditions moderate the influence of emotions?

5. How do leadership strategies influence the emotions of bureaucrats?

a. Which leadership strategies increase enthusiasm and energy?

b. Which leadership strategies increase vigilance and thoughtfulness?

c. Which (if any) leadership strategies can secure both a. and b. simultaneously?

6. How do emotions (anger, anxiety/fear, enthusiasm) influence citizens' interaction with public agencies? Specifically, what is the effect on:

a. Motivations to comply with rules, regulations and administrative decisions?

b. Motivations to cooperate and engage in co-production with service providers?

Both the behavior of bureaucrats and citizens who interact with public agencies may be influenced by emotions. If discrete emotions involve different behavioral tendencies, both managers inside bureaucracies and officials who interact with citizens outside bureaucracies should carefully think not only about the accuracy of the information they convey but also the emotions they invoke. Specifically and to take an example, the role of emotions for citizen engagement in public service production has never been studied. The discussion on how to make citizens take an active part in the co-production of public services has focused on the importance of citizen resources (e.g. SES variables), cognitive motivations (related to understandings), and incentives (Percy, 1984; Thomsen \& Jakobsen, 2015). A recent review suggests that 'expressive incentives' should also be taken into account (van Eijk \& Steen, 2014), but so far the coproduction literature has made little systematic effort to understand how emotional rather than cognitive motivations may induce citizens to invest in co-production initiatives, in particular initiatives that involve the production of collective goods. Following the literature we should expect enthusiasm and joy to fuel co-production efforts, and perhaps more so than information with cognitive appeals.

Question 5, and particularly question 5a, has received much attention in generic leadership and management studies. For instance research shows that perceived leader charisma and positive affect influence follower affect by way of an 'emotional contagion effect' and that positive affect among followers increases (self-reported) contextual performance (Johnson, 2008). This suggests a leader effect on enthusiasm and energy; but following Affective Intelligence Theory, we expect increasing enthusiasm to be accompanied by less vigilance and thoughtfulness. In general we expect emotions to have both desirable and undesirable behavioral consequences (questions $4 \mathrm{a}$ and $4 \mathrm{~b}$ ); this will probably also be the case in public bureaucracies, at least those that are weakly regulated by rules and standard operating procedures. Following the literature, it will be difficult for leaders to simultaneously nurture energetic, loyal and goal-congruent behavior and vigilant, thoughtful and critical judgment and decision-making (question 5c). The importance of emotionally triggered motivations and behaviors is likely to vary across organizational context and task, but a focus on the effect of emotions seems a promising approach to the study of intended and unintended consequences of leadership strategies in public bureaucracies.

\section{Group Identity and Motivated Reasoning}

Intuitive and fast thinking and emotionally triggered behavior that relies on 'standing dispositions' make the question of which dispositions that matter highly pertinent. Groups and group identity are important sources of motivational bias that may be relevant also in bureaucratic behaviors. This is not the place to review all theories of groups (see Huddy, 2013); building on the insights from Social 
Identity Theory (Tajfel, 1981; Huddy, Mason, \& Aarøe, 2015), it suffices to say that the stronger one's sense of belonging and the more cohesively one self-identifies with a certain group the more important the group identity will be for the thoughts, feelings and behaviors of an individual. Strong group identifiers have in-group biases, generally feel enthusiastic about their group and want to protect and advance it, in particular when challenged and threatened. But strong group identifiers may also have feelings of out-group hostility when they feel threatened and insecure. Public bureaucracies, not least if they have a strong sense of mission and a coherent culture, may be a source of group identity as Simon suggested. But so can sub-units within the organization (Cyert \& March, 1963) and groups (ethnic, gender, professions etc.) outside the organization.

Studies of representative bureaucracy generally do not build on Social Identity Theory but they can be used to illustrate how bureaucrats' social identities shape their behavior towards citizens belonging to the in-group and how in-groups and out-groups may perceive the legitimacy of decisions made by bureaucrats. In the first place you may argue that the whole idea of (a need for) representative bureaucracy rests on the idea that the group identity of bureaucrats, whether rooted in gender, race or other socio-demographic characteristics, may matter for legitimacy and decisions. Evidence shows that in a host of situations minority groups such as Latinos or blacks benefit when the minority group representation in a bureaucracy is high (Meier, 1993; Meier, Wrinkle, \& Polinard, 1999) and feel more fairly treated by street-level bureaucrats like teachers and police officers of the same race (Theobald \& Haider-Markel, 2009). Often bureaucracies that are more representative of minority groups make decisions that benefit the minority groups (Meier, 1993), and perhaps without disadvantaging the non-minority group (Meier et al., 1999). But rightly or wrongly, the majority group may still perceive the actions taken by an out-group, street-level bureaucrat as unfair (Theobald \& Haider-Markel, 2009). Building on Social Identity Theory a recent study found that senior civil servants who identify with protesting social groups are more responsive to grievances and demands voiced by their in-group (Gilad \& Alon-Barkat, 2017).

Group identity and psychological and political orientations more generally may bias judgment and decision-making. Politically motivated reasoning involves confirmation and disconfirmation biases (Leeper \& Slothuus, 2014). Information from groups with whom you agree and feel attached, and messages you already are disposed to believe are ones that you will easily adapt to and accept. If you dislike the conveyer of a piece of information or the content challenges your standing dispositions, you tend to question the validity of the information and, quite possibly, disregard it when you make judgments and decisions. Following group theory and theories of politically motivated reasoning, human beings are less preoccupied with 'getting the facts right' than with 'getting the right facts', although there are limits as to how long individuals reject uncomfortable facts when disconfirming information piles up (Redlawsk, Civettini, \& Emmerson, 2010). Motivated reasoning both involves System 1 and System 2 judgment and decision-making and works both as informational shortcuts (cognitive and slow) and through simple object identification (associational and fairly emotional).

Recently theories of politically motivated reasoning have found their way into public administration with a few important applications, e.g. regarding getting performance information right, and motivation effects apply both to citizens (Baekgaard \& Serritzlew, 2016; James \& Van Ryzin, 2017) and, even more so, their political leaders (Baekgaard, Christensen, Dahlmann, Mathiasen, \& Petersen, 2017). However, both theories of group identity and motivated reasoning can find much broader applications within public administration.

As the example of representative bureaucracy shows, thinking in groups and group identities is by no means foreign to public administration, but psychological theories of group identity and motivated reasoning add nuance to well-established theories such as representative bureaucracy and may provide a much needed theory of the micromechanism at work (cf. Gilad \& Alon-Barkant, 2017). The potential, positive effects of being symbolically represented (cf. Theobald \& Haider-Markel, 2009; Riccucci, Van Ryzin, \& Li, 2016) will likely depend on the strength and coherence of bureaucrats' group identity, and in some situations, e.g. when a group feels threatened, strong group identification may also lead to adverse decisions and outright discrimination against out-groups. More importantly, theories of group identity and motivated reasoning suggest that the ubiquitous norm saying that bureaucrats should always try 'to get the 
facts right' cannot be taken for granted. Theorizing from the perspective of motivated reasoning, it is probably a quite daunting task to ensure that public bureaucrats observe this norm when making concrete judgments and decisions.

7. Which group identities are prevalent within various public agencies?

a. What is the consequence of representative vs. non-representative bureaucracy?

b. Does a general public service motivation/ethos trump more parochial identities?

c. When is the agency the object of group identity and loyalty (cf. Simon)?

8. How common is motivated reasoning in administrative judgment and decisions?

a. Which priors inform motivated reasoning among bureaucrats?

b. To what extent do bureaucrats reject 'uncomfortable' factual information?

c. Can management, rules and professional norms counter motivated reasoning?

9. What are the effects of group identities for administrative behavior?

a. Is strong group identity associated with in-group loyalty and out-group animosity?

b. Do 'threats' and task conditions moderate identity effects?

\section{Anthony Downs - 'Types of Officials' and Differences in Bureaucratic Behavior}

Downs builds on Simon's work and a vast literature on organizations to develop a rich, empirically focused theory of behavior inside public bureaucracies. In the summary he lists three central hypotheses, 16 'laws', 183 propositions, and numerous subpropositions (Downs, 1967, pp. 261-280). He anticipates a number of themes regarding the enduring inefficiencies in (public) bureaucracies that are more fully theorized in later work based on e.g. principal-agent and transaction cost theories. In general, he builds on a rational choice framework and how incentives Inside Bureaucracy shape behavior. Downs expects most bureaucrats, especially at the higher echelons of public bureaucracies, to be advocates of their bureau and the functions it fulfills (Downs, 1967, pp. 103-109). But in this context his most important contribution concerns the central claim that individuals have different psychological dispositions and that different 'types of officials' in large measure will react differently to the same organizational rules and incentives.

Downs talks about five "oversimplified" ideal-types of bureaucrats, the well-known Climbers, Conservers, Zealots, Advocates and Statesmen (Downs, 1967, in particular chapters 7, 8 and 9). Whereas the former two have highly different goals and motivations, with ambitious climbers yearning for power, income, prestige and 'aggrandizement' and complacent conservers hoping for job security, convenience and keeping "What You've Got", they are both motivated "almost entirely by goals that benefit themselves" (Downs, 1967, pp. 96, 88, 92-101). The remaining three types of officials also pursue self-interests, but in addition they are also motivated by other-regarding, or 'altruistic', goals and values.

Zealots or 'fanatics' have the narrowest other-regarding goals, usually a 'sacred policy' or program. They resemble our stereotypical idea of a somewhat confused, highly energetic but a bit socially unaware scientist (Downs' example is a developer of nuclear submarines) who devotes all his time and resources to the cause and would like others to do the same. Zealots can be entrepreneurs in their narrow field of attention, but they do not have imperial ambitions. Advocates are not nearly as fanatic, but compared to the zealot they focus on a broader set of functions and interests beyond themselves. They are energetic, innovative, open to new ideas about how to do things, and - importantly - they are more other-regarding and oriented towards social approval. Therefore, they are more sensitive to colleagues and superiors, and they often assume leadership positions. An "advocate is highly partisan externally, but an impartial arbiter internally (Downs, 1967, p. 108). Finally, statesmen are motivated by what is best for society as a whole; and because they do not sufficiently protect the interests of their agency, they are rare species in public bureaucracies (Downs, 1967, p. 111). Far less fanatic than zealots, statesmen typically also appear less energetic and assertive and more introverted 
and contemplative, all characteristics that may explain why few statesmen are (top) leaders (cf. Judge, Bono, Ilies, \& Gerhardt, 2002).

Following Downs, behavior is shaped both by the bureaucrat's personality, the position they hold and the organizational context in which they find themselves. Downs puts much emphasis on position, context and incentives, but he also continuously stresses the importance of the "basic structure of each individual's personality" that has "normally 'hardened' into patterns" that are extremely hard to change. Therefore, management should focus on recruitment rather than try to alter "the diverse goals of individuals already in the organization" (Downs, 1967, p. 229). The behavior resulting from "the reciprocal relationship between psychological characteristics and official position requirements" is hard to predict (Downs, 1967, p. 90). But in general officials "will exhibit the behavior patterns of the type to which they are psychologically predisposed unless they are constrained from doing so by a narrow definition of their official position or by the perceived impossibility" of pursuing their goals and motivations within the organization (Downs, 1967, p. 90). Downs goes on to predict that an official will become "more deeply committed" to his or her type of behavior "the more successful it is", although he also recognizes that the tenacity of any official is itself partially a result of psychological proclivities inherent to his or her personality (Downs 1967, pp. 90, 89).

In Downs' conception of psychological differences a person's 'ultimate', 'basic personal' and 'social conduct' goals are fundamental and prior to the bureau's goals and requirements although individuals to varying degrees adapt their personal goals to the organization. Downs "makes no pretense of knowing enough about psychology" to explicate the interrelation between the several layers of individuals' goals and motivation (Downs, 1967, p. 85), but his intuitions in notable respects resemble recent discussions in personality trait psychology.

\section{Beyond Downs - Personality Traits and Differences in Bureaucratic Behavior}

Although all individuals are prone to the general psychological reactions and processes discussed above, individuals also have different goals and motivations, react emotionally and cognitively differently to the same situations and stimuli, and behave differently even if placed under the same rules, occupying similar positions and facing identical incentives. Anthony Downs' acknowledged this and came up with his intuitive typology of officials.

A point of departure in personality psychology is more promising because building on this prolific literature, we get firmer empirical ground under our feet, more nuances and a more rigorously tested theory of individual differences in motivation and behavior that can inform behavioral public administration. I briefly introduce personality trait theory before discussing how it can inform the study of bureaucratic behavior.

\section{Personality Traits}

Personality traits can be defined as a set of dynamic, self-regulatory internal psychological systems that "guide affective, cognitive, and motivational processes, directing people toward achieving individual and collective goals" (Caprara, Schwartz, Capanna, Vecchione, \& Barbaranelli, 2006, p. 3). Personality traits are the result of a complex interplay between nature and nurture (Bouchard \& McGue, 2003). They become increasingly stable in young adulthood and remain fairly stable until old age (Caspi, Robert, \& Shiner, 2005; Roberts \& DelVecchio, 2000). That is, personality traits are fairly stable dispositions that people bring with them to different contexts; and they are, as also Downs realized, hard to change. Traits are dispositions that typically, but not always guide individual behavior (Fleeson \& Gallagher, 2009); all individuals can behave in a counter-trait way, but unless they face strong situational constraints they will typically not do so. Just like self-interested behavior, inclinations related to personality traits can be partially tamed.

In personality psychology there is a wide consensus that individual differences at a certain level of generalization can be described by five, broad personality traits, the so-called Big Five or Five Factor Model (FFM) (Goldberg, 1992; Costa \& McCrae, 1992; McCrae \& Costa, 1997; John, Naumann, \& Soto, 2008). The Big Five traits are Openness to Experience, Conscientiousness, Extraversion, Agreeableness and Neuroticism (or its inverse: Emotional Stability). Openness includes a preference for art and aesthetics, intellectual activities, new ideas and experiences and an openminded approach to life. Conscientiousness involves orderliness, dutifulness, adherence to social norms, a high degree of impulse control and a 
strong achievement and goal orientation. Extraversion is associated with high levels of energy, positive emotionality, sociability, assertiveness and riskacceptance. Agreeableness comprises characteristics such as tender-mindedness, pro-social orientation, politeness, modesty, compassion and empathy. Finally Neuroticism includes a tendency to experience negative emotions, impulsivity, vulnerability and anxiety and an inclination to withdraw when a social situation is new or feels threatening. Neuroticism correlates so strongly negatively with locus of control and self-efficacy that these dispositions may be seen as the same construct (Judge, Erez, Bono, \& Thoresen, 2002).

\section{Personality Traits and Individual Differences in Bureaucratic Behavior}

Although some personality traits correlate (e.g. Conscientiousness and Neuroticism correlate negatively), any individual can have highly different scores on the five traits. Thus, contrary to Downs, personality trait theory is not preoccupied with "oversimplified" ideal-types of persons, whether in their capacity as officials or in other situations. Rather, the goal is to provide a generic theoretical framework for measuring personality traits as scales and developing predictions of behavioral correlates, or 'characteristic adaptations' as it is often called, of these traits. Effects of combinations of traits will typically be assessed as interaction terms (or as clusters), e.g. the effect of high Conscientiousness at varying levels of Extraversion. As deep-seated dispositions personality traits undoubtedly influence behaviors in bureaucratic settings, but we should also expect that domain-specific constraints may suppress trait effects and some level of self-selection suggesting that some personality traits are more likely among bureaucrats.

Below, I discuss for each trait the prevalent behavioral and attitudinal correlates emphasizing behaviors that are relevant to bureaucrats in public agencies. Although there is important research on personality traits in personnel, industrial and organizational psychology, the research in public administration is rather embryonic (cf. Wright, 2015; van Witteloostuijn, Esteve, \& Boyne, 2017). Therefore the discussion mostly relies on literature outside Public Administration. Since I rely on the same literature for all traits, I avoid extensive repetitive referencing in the text. References are listed in the note to Table 1 below.

\section{Openness}

Individuals who are open to new experiences often have a high level of education and do well in school, they are often creative in their jobs, and they are tolerant towards other people and opinions. In their relation with other people they are often forgiving. Open individuals like to think about complex and intellectually stimulating issues. Openness correlates positively with the psychological construct 'need for cognition' and negatively with dogmatism (Jost, Glaser, Kruglanski, \& Sulloway, 2003). Openness is also associated with a motivation to learn new things on the job, and open people are often good communicators that cope well with organizational change (Judge, Thoresen, Pucik, \& Welbourne, 1999). Generally openness is not related to job motivation and performance, and it is not a strong predictor of leadership behavior. We may conjecture that a host of administrative positions in public bureaucracies appear unappealing to individuals who score high on openness, but innovative tasks should be appealing.

\section{Conscientiousness}

This trait predicts a number of desirable outcomes. Conscientious people generally have good relations with partners, family, peers and colleagues because they are dependable and trustworthy. The trait is associated with strong impulse control, academic achievement and 'getting the job done'. Conscientious people tend to be orderly and disciplined and therefore live longer. They rarely engage in risky behaviors and crime. Conscientiousness predicts conservatism and a preference for social order. Conscientious individuals are highly motivated and perform well on the job, they usually demonstrate persistence and tenacity in the pursuit of organizational goals, and they also often make it to leadership positions because they are high achievers. Conscientiousness is a highly desirable trait in bureaucrats who are expected to abide rules meticulously in exercising their duties, and we may expect highly conscientious individuals to be attracted to a bureaucratic career. Conscientious people will likely be good organizers and designers of bureaucratic procedures.

\section{Extraversion}

Extrovert individuals are outgoing and positive, and they easily make new acquaintances. They are usually likable and have good relations with family, friends and colleagues. They are good networkers. 
Extraversion is associated with general subjective well-being and job satisfaction and motivation. Extroverts are usually highly committed. An aspect of extraversion is assertiveness and the urge to be the center of attention (DeYoung, Quilty, \& Peterson, 2007). Hence, not surprisingly extraversion is a strong predictor of assuming leadership positions, and it is the "strongest and most consistent correlate of transformational leadership" (Bono \& Judge, 2004, p. 901). Extrovert individuals are probably also more likely to assume leadership positions in a bureaucratic context, but with a proclivity to make risky and hasty decisions they may "fail to provide a clear strategic focus for followers" (Judge, Piccolo, \& Kosalka, 2009, p. 868). Therefore, extraversion may not be equally positively associated with (leadership) performance in all types of public bureaucracies. Extroverts probably do not see jobs that involve rule-application and a narrow role-definition as appealing vocations.

\section{Agreeableness}

Agreeable individuals easily empathize with people in need, they are forgiving of misdeeds, and they are generally polite in social interactions. They have good relations with partners, family and close friends as well as colleagues and more distant acquaintances, but agreeable people typically do not take the initiative to network. Agreeable people often engage in volunteerism and good citizenship behavior, and they are not preoccupied with extrinsic tokens of success. They perform well in teams, but they shy away from conflicts and decisions that may have detrimental consequences for other people. Therefore, even if agreeable individuals usually have good interpersonal skills and the trait is positively associated with some aspects of leadership behavior, in general agreeableness is negatively associated with assuming a leadership position (Judge, Bono et al., 2002; Bono \& Judge, 2004). Also in a public sector context, agreeable individuals are unlikely to become leaders, but if they do they may do well as leaders in agencies that adhere to the status quo (Judge et al., 2009) and in leadership functions that involve intensive interaction with staff and clients in need.

Neuroticism (or Its Inverse: Emotional Stability) Emotionally unstable individuals who are prone to experience negative feelings do not do well in most social situations. They tend to have poor relations with partners, family and friends; and relationships are frequently dissolved. They are often not satisfied in their jobs; they often lack commitment and may experience many job shifts. Emotional stability seems to be a prerequisite for assuming leadership positions. Emotionally unstable individuals are more prone to stress and therefore they dislike uncertainty and frequent changes in their environment. Also in the context of most public bureaucracies a certain level of emotional stability is a prerequisite of doing well, but in routine situations that involve paying close attention to details neuroticism may be less of a liability.

Table 1 below summarizes (a) the Big Five traits, (b) the main trait descriptors, and (c) behavioral and attitudinal correlates outside bureaucracy. It also includes hypotheses on (d) how personality traits may be related to behaviors that are relevant inside public bureaucracies, and in italics it highlights the type of tasks that individuals with a high trait score may be likely to perform well (for simplicity assuming other traits constant). Individuals who are high in Extraversion or Openness will probably not do well performing routine tasks day in and day out. Nor can we expect that an emotionally unstable and vulnerable person will do well in performing highly different and challenging tasks. Not only the person-organization fit but also the person-task fit is likely to be important for individual bureaucratic behavior.

The question is, of course, to what extent the characteristics of public administration or 'publicness' (Bozeman \& Bretschneider, 1994) gives reason to believe that the 'characteristic adaptations', i.e. behavioral correlates, of personality traits will be different in public administration, or if the skills and motivations of public leaders are entirely different from those of private leaders (Tummers \& Knies, 2016). I very much doubt that this will generally be the case, not least because public agencies and organizations are highly heterogeneous: both mechanisms of selection/recruitment and of self-selection may be quite different in the Foreign Ministry, the military and public schools. The fact that one has to theorize, on a fairly broad and yet precise level of generalization, what is specific about public administration is one of the advantages of starting out with a general theory of individual psychological differences. This opens for a promising research agenda for behavioral public administration: 
10. Which personality traits are dominant in public organizations?

a. To what extent are they different from those dominant in private organizations?

b. How do they differ across types of tasks, positions and agencies?

c. Is the dominance of particular traits a result of self-selection or recruitment?

11. When and how do personality traits influence administrative decisions?

a. When do roles, situational imperatives and task conditions matter more?

b. Is Public Service Motivation and professionalism rooted in personality traits?

c. Which personality traits are associated with different public leadership behaviors?

12. How important are personality traits for official-client relations?

a. How do personality traits influence officials' responsiveness to clients?

b. Is trait congruence important for clients feeling symbolically represented?

c. Do personality traits influence the proclivity to rely on heuristics and emotions in the interaction with clients?

To put it bluntly, the big question is if the tenets of personality psychology are right in arguing that fairly universal individual differences in motivations and needs typically will lead to trait-conforming behaviors across domains, sectors and situations, or if time-honored research in public administration is right in arguing that e.g. leadership styles, rules and routines, organizational goals and missions, contextual incentives, professional training and task conditions are important sector-specific determinants of behavior in public agencies. If the former is true, focus should be on recruiting the right people. In addition to selection based on professional training and skills this includes hiring a staff with the personality traits that are most conducive to performing well in the job, no matter whether this is in the public or private sector. Only if the public context somehow matters will there be a genuine behavioral public administration that can claim to shed light on human behaviors that are characteristic, typical and distinctive for public bureaucracies.

For some behaviors in public administration contextual inducements and constraints will undoubtedly be important, but the public domain characteristics may be less important for other behaviors and motivations. For instance, Cooper and associates find Neuroticism and Extraversion to predict job satisfaction among teachers in public schools (cf. Cooper, Carpenter, Reiner, \& McCord 2014). This finding echoes a meta-study of 163 samples that overwhelmingly come from private sector settings (Judge, Heller, \& Mount, 2002).

Personality traits may also be antecedents of constructs that are important for bureaucratic behavior. Until recently the public service motivation (PSM) literature has hardly paid attention to personality traits (cf. reviews by Perry, Hondeghem, \& Recascino Wise, 2010; Perry \& Vandenabeele, 2015), but two recent studies have shown that the four aspects usually subsumed under PSM are related to individual differences in personality traits (Jang, 2012; van Witteloostuijn et al., 2017). Unsurprisingly, both find substantial effects of personality traits on PSM, with Agreeableness predicting the compassion aspect of PSM.

\section{Future Directions for Behavioral Public Administration}

Following Herbert Simon and Anthony Downs behavioral public administration has to look beyond the literature in the field and get inspiration from all the behavioral sciences, not least psychology. The 12 questions I have raised are but a subset of the important issues that a behavioral public administration should address to get a better understanding of how real bureaucrats behave and decide. Lessons from psychology seem ubiquitous.

It is a great advantage to behavioral public administration to build on general psychological theories of human behavior and validated constructs with good psychometric properties rather than to begin de novo fashioning field-specific 
Table 1

Personality traits: Descriptors, behaviors \& 'types of officials'

\begin{tabular}{|c|c|c|c|}
\hline (a) Traits & (b) Trait descriptors & $\begin{array}{l}\text { (c) Behaviors and attitudes, } \\
\text { outside bureaucracy }\end{array}$ & $\begin{array}{l}\text { (e) Behaviors, relevant } \\
\text { inside bureaucracy }\end{array}$ \\
\hline Openness & $\begin{array}{l}\text { Intellectuality, } \\
\text { open-minded, creative, } \\
\text { artistic }\end{array}$ & $\begin{array}{l}\text { Forgiveness } \\
\text { Level of education } \\
\text { Liberal orientation } \\
\text { Party switching }\end{array}$ & $\begin{array}{l}\text { Training proficiency } \\
\text { Communication } \\
\text { Job creativity } \\
\text { Innovation tasks? }\end{array}$ \\
\hline Conscientiousness & $\begin{array}{l}\text { Orderly, achievement, task } \\
\text { oriented, duty, self-control }\end{array}$ & $\begin{array}{l}\text { Long lives } \\
\text { Peer and family relations } \\
\text { Academic achievement } \\
\text { Substance abuse (-) } \\
\text { Conservative orientation }\end{array}$ & $\begin{array}{l}\text { Performance motivation } \\
\text { Job performance } \\
\text { (Leadership behavior) } \\
\text { Organizational design tasks? }\end{array}$ \\
\hline Extraversion & $\begin{array}{l}\text { Enthusiasm, excitement, } \\
\text { assertiveness, sociability }\end{array}$ & $\begin{array}{l}\text { Long lives } \\
\text { No of friend \& sex partners } \\
\text { Approach strangers } \\
\text { Depression }(-)\end{array}$ & $\begin{array}{l}\text { Leadership behavior } \\
\text { Performance motivation } \\
\text { Job commitment/ } \\
\text { satisfaction } \\
\text { External relations, } \\
\text { networking } \\
\text { PR \& mission-building tasks? }\end{array}$ \\
\hline Agreeableness & $\begin{array}{l}\text { Compassion, politeness, } \\
\text { tender-minded, modesty }\end{array}$ & $\begin{array}{l}\text { Performance in groups } \\
\text { Peer \& family relations } \\
\text { Partner relations } \\
\text { Religiosity }\end{array}$ & $\begin{array}{l}\text { Performance in groups } \\
\text { Interpersonal relations } \\
\text { Job length } \\
\text { Personnel \& HR tasks? }\end{array}$ \\
\hline $\begin{array}{l}\text { Neuroticism } \\
(-) \text { Emotional } \\
\text { Stability }\end{array}$ & $\begin{array}{l}\text { Anxiety, volatility, negative } \\
\text { emotions, impulsiveness }\end{array}$ & $\begin{array}{l}\text { Family relations (-) } \\
\text { Depression } \\
\text { Romantic relations (-) } \\
\text { Academic achievement (-) }\end{array}$ & $\begin{array}{l}\text { Leadership behavior }(-) \\
\text { Performance motivation }(-) \\
\text { Job performance }(-) \\
\text { Job changes } \\
\text { Routine tasks? }\end{array}$ \\
\hline
\end{tabular}

Note: The literature used for characterizations include, (b): Costa and McCrae, 1992; McCrae and Costa, 1997; John et al., 2008; (c): Ozer and Benet-Martínez, 2006; John et al., 2008; Bakker, Klemmensen, Nørgaard, \& Schumacher, 2016 (d): Barrick and Mount, 1991; Barrick, Mount, \& Gupta, 2003; Judge, Bono et al., 2002; Bono and Judge, 2004; Judge and Ilies, 2002; Judge et al., 2009. A characteristic followed by (-) is negatively related to the personality trait.

constructs and theories. First, doing so compels scholars in behavioral public administration to be specific on how, why and to what extent the behavior in public bureaucracies is different from behavior in other social and organizational contexts and to think twice before devising new domain-specific constructs that, of course, may be important too (e.g. Kim et al., 2013). Second and relatedly, behavioral public administration will get a head start in developing domain specific theories and hypotheses that rest on solid theoretical and empirical foundations about human behavior.

My argument for how a prolific behavioral public administration can thrive is neither new nor 
original. Seventy years ago Simon's and Downs' contemporary, Robert A. Dahl, argued that a science of public administration implies first "the development of a science of man" and second a focus on "that region of human activity" that falls within "the area of services administered by the public" (Dahl, 1947, p. 7). Thus, what we today call behavioral public administration is a conditio sine qua non of a science of public administration according to Dahl. The alternative, to build on intuitions and field specific research only, will thwart the ambition to develop general theories of human behavior in public administration, and it will reduce the relevance of this promising new field not only inside public administration, but also - which is equally important - outside public administration.

\section{Acknowledgement}

Thanks to Robert Klemmensen, Martin Bækgaard and two anonymous reviewers for helpful comments and suggestions.

\section{References}

Angie, A. D., Connelly, S., Waples, E. P., \& Kligyte, V. (2011). The influence of discrete emotions on judgement and decision-making: A meta-analytic review. Cognition and Emotion, 25, 1393-1422.

Baekgaard, M., \& Serritzlew, S. (2016). Interpreting Performance Information, Motivated Reasoning or Unbiased Comprehension . Public Administration Review, 76, 73-82.

Baekgaard, M., Christensen, J., Dahlmann, C., Mathiasen, A., \& Petersen, N. (2017). The Role of Evidence in Politics: Motivated Reasoning and Persuasion among Politicians. British Journal of Political Science, 1-24. doi:10.1017/S0007123417000084

Bakker, B., Klemmensen, R., Nørgaard, A. S., \& Schumacher, G. (2016). Stay Loyal or Exit the Party? How Openness to Experience and Extroversion Explain Vote Switching. Political Psychology, 37, 419429.

Barrick, M. R., \& Mount, M. K. (1991). The Big Five personality dimensions and job performance: A meta-analysis. Personnel Psychology, 44, 1-26.

Barrick, M. R., Mount, M. K., \& Gupta, R. (2003). Meta-analysis of the relationship between the fivefactor model of personality and Holland's occupational types. Personnel Psychology, 56, 45-74.

Blanchette, I., \& Richards, A. (2010) The influence of affect on higher level cognition: A review of research on interpretation, judgement, decision making and reasoning. Cognition and Emotion, 24, 561-595.

Bono, J. E., \& Judge, T. A. (2004). Personality and Transformational and Transactional Leadership: A Meta-Analysis. Journal of Applied Psychology, 89, 901910.

Bouchard, T. J., \& McGue, M. (2003). Genetic and Environmental Influences on Human Psychological Differences. Journal of Neurobiology, 54, 4-45.

Bozeman, B., \& Bretschneider, S. (1994). The 'publicness puzzle' in organization theory: A test of alternative explanations of differences between public and private organizations. Journal of Public Administration Research and Theory, 4, 197-224.

Brader, T. (2006). Campaigning for hearts and minds: How emotional appeals in political ads work. Chicago: University of Chicago Press.

Brader, T. \& Marcus, G. E. (2013). Emotion and Political Psychology. In L. Huddy, D. Sears, \& J. Levy (Eds.), Oxford Handbook of Political Psychology, 2nd Edition. Oxford University Press. pp. 165-204.

Brehm, John, \& Gates, S. (1997). Working, shirking, and sabotage: Bureaucratic response to a democratic public. Ann Arbor, MI: University of Michigan Press.

Caprara, G. V., S. Schwartz, C. Capanna, M. Vecchione, \& Barbaranelli, C. (2006). Personality and Politics: Values, Traits, and Political Choice. Political Psychology, 27, 1-28.

Caspi, A., Roberts, B. W., \& Shiner, R. L. (2005). Personality Development: Stability and Change. Annual Review of Psychology, 56, 453-84.

Cooper, C. A., Carpenter, D., Reiner, A., \& McCord, D. (2014). Personality and job satisfaction: Evidence from a sample of street-level bureaucrats. International Journal of Public Administration, 37, 15562.

Costa, P. T., \& McCrae, R. R. (1992). Four ways five factors are basic. Personality and Individual Differences, 13, 653-665.

Cosmides, L., \& Tooby, J. (1996). Are humans good intuitive statisticians after all? Rethinking some conclusions from the literature on judgment under uncertainty. Cognition, 58, 1-73.

Cyert, R. M., \& March, J. G. (1963). A Behavioral Theory of the Firm. Englewood Cliffs, NJ: . Prentice-Hall.

Dahl, R. A. (1947). The Science of Public Administration: Three Problems. Public Administration Review, 7, 1-11.

DeYoung, C. G., Quilty, L. C. \& Peterson, J. B. (2007). Between facets and domains: Ten aspects of the Big Five. Journal of Personality and Social Psychology, 93, 880896. 
Downs, A. (1967). Inside Bureaucracy. Prospect Heights, Ill: Waveland Press.

Fleeson, W., \& Gallagher, P. (2009). The implications of Big Five standing for the distribution of trait manifestation in behavior: Fifteen experiencesampling studies and a meta-analysis. Journal of Personality and Social Psychology 97, 1097-1114.

Gigerenzer, G., \& Goldstein, D. G. (1996). Reasoning the fast and frugal way: models of bounded rationality. Psychological Review, 103, 650-669.

Gilad, S. \& Alon-Barkat, S. (2017). Enhancing democracy via bureaucracy: Senior managers' social identities and motivation for policy change. Governance. DOI: 10.1111/gove.12300

Goldberg, L. R. (1992). The development of markers for the big-five factor structure. Psychological Assessment, 4, 26-42.

Grimmelikhuijsen, S., Jilke, S., Leth Olsen, A. \& Tummers, L. (2017). Behavioral Public Administration: Combining Insights from Public Administration and Psychology. Public Administration Review, 77, 45-56

Huddy, L., Feldman, S., Taber, C., \& Lahav, G. (2005). Threat, anxiety, and support of antiterrorism policies. American Journal of Political Science, 49, 610625.

Huddy, L., Feldman, S., \& Cassese, E. (2007). On the distinct political effects of anxiety and anger. In W. R. Neuman, G. E. Marcus, M. Mackuen, \& A. N. Crigler (Eds.), The affect effect: Dynamics of emotion in political thinking and behavior. Chicago: University of Chicago Press. pp. 202-230.

Huddy, L. (2013). From group identity to political cohesion and commitment. In L. Huddy, D. Sears, J. \& Levy (Eds.). Oxford Handbook of Political Psychology. 2nd Edition. New York: Oxford University Press. pp. 737-773.

Huddy, L., Mason, L., \& Aarøe, L. (2015). Expressive partisanship: Campaign involvement, political emotion, and partisan identity. American Political Science Review, 109, 1-17.

James, O., \& Van Ryzin, G.G. (2017). Motivated Reasoning about Public Performance: An Experimental Study of How Citizens Judge the Affordable Care Act. Journal of Public Administration Research and Theory, 27, 197-209.

Jang, C-L. (2012). The effect of personality traits on Public Service Motivation: Evidence from Taiwan. Social Behavior and Personality, An International Journal, 40, 725-33.

Jilke, S., Van de Walle, S., \& Kim, S. (2016). Generating Usable Knowledge through an Experimental Approach to Public Administration. Public Administration Review, 76, 69-72. .

John, O. P., Naumann, L. P. \& Soto, C. J. (2008). Paradigm Shift to the Integrative Big Five Trait Taxonomy. In O. P. John \& C. J. Soto (Eds.),
Handbook of Personality: Theory and Research. New York: Guilford Press. pp. 114-58.

Johnson, E. J., \& Tversky, A. (1983). Affect, generalization, and the perception of risk. Journal of Personality and Social Psychology, 45, 20-31.

Johnson, S. K. (2008). I second that emotion: Effects of emotional contagion and affect at work on leader and follower outcomes. The Leadership Quarterly, 19, $1-19$.

Jost, J. T., Glaser, J., Kruglanski, A. W., \& Sulloway, F. J. (2003). Political Conservatism as Motivated Social Cognition. Psychological Bulletin May, 129, 339-75.

Judge, T. A., Thoresen, C. J., Pucik, V., \& Welbourne, T. M. (1999). Managerial coping with organizational change, A dispositional perspective. Journal of Applied Psychology, 84, 107-122.

Judge, T. A., Bono, J. E., Ilies, R., \& Gerhardt, M. W. (2002). Personality and Leadership: A Qualitative and Quantitative Review. Journal of Applied Psychology, 87, 765-80.

Judge, T. A., Erez, A., Bono, J. E., \& Thoresen, C. J. (2002). Are Measures of Self-Esteem, Neuroticism, Locus of Control, and Generalized Self-Efficacy Indicators of a Common Core Construct?. Journal of Personality and Social Psychology, 83, 693-710.

Judge, T. A., Heller, D., \& Mount, M. K. (2002). Five factor model of personality and job satisfaction: A meta-analysis. Journal of Applied Psychology, 87, 530541.

Judge, T. A., \& Ilies, R. (2002). Relationship of personality to performance motivation: A metaanalytic review. Journal of Applied Psychology, 87, 797807.

Judge, T. A., Piccolo, R. F. \& Kosalka, T. (2009). The bright and dark sides of leader traits: A review and theoretical extension of the leader trait thematic category. Leadership Quarterly, 20, 855-875.

Kahneman, D. (2000). A psychological point of view: Violations of rational rules as a diagnostic of mental processes. Behavioral and Brain Sciences, 23, 681-683.

Kahneman, D. (2011). Thinking, Fast and Slow. New York: Farrar, Straus and Giroux.

Kahneman, D., \& Tversky, A. (1996) On the reality of cognitive illusions. Psychological Review, 103, 582-91.

Kim, S., Vandenabeele, W., Wright, B. E., Bøgh Andersen, L., Cerase, F. P., Christensen, R. K., et al. (2013). Investigating the Structure and Meaning of Public Service Motivation across Populations: Developing an International Instrument and Addressing Issues of Measurement Invariance. Journal of Public Administration Research and Theory, 23, 79-102.

Kunda, Z. (1990). The case for motivated reasoning. Psychological Bulletin, 108, 480-498.

Lazarus, R. S. (1991). Progress on a cognitivemotivational-relational theory of emotion. American Psychologist, 46, 819-834. 
Leeper, T. J., \& Slothuus, R. (2014). Political parties, motivated reasoning, and public opinion formation. Political Psychology, 35(S1: Advances in Political Psychology), 129-156.

Lerner, J. S., \& Keltner, D. (2000). Beyond valence: Toward a model of emotion-specific influences on judgement and choice. Cognition and Emotion, 14, 473493.

Lipsky, M. (1980). Street-Level Bureaucracy. New York: Russell Sage Foundation

List, J. A. (2003). Does Market Experience Eliminate Market Anomalies? Quarterly Journal of Economics, 118, 41-71.

March, J. G., \& Olsen, J. P. (1989). Rediscovering institutions: The organizational basis of politics. New York: The Free Press.

Marcus, G. E., Neuman, W. R., \& MacKuen, M. (2000). Affective Intelligence and Political Judgment. Chicago: University of Chicago Press.

May, P. J., \& Winter, S. C. (2009). Politicians, Managers, and Street-Level Bureaucrats: Influences on Policy Implementation. Journal of Public Administration Research and Theory, 19, 453-476.

McAdams, D. P., \& Pals, J. L. (2006). A new Big Five: Fundamental principles for an integrative science of personality. American Psychologist, 61, 204-217.

McCrae, R. R., \& Costa, P. T. (1997). Personality trait structure as a human universal. The American Psychologist, 52, 509-16.

Meier, K. J. (1993). Latinos and Representative Bureaucracy: Testing the Thompson and Henderson Hypotheses. Journal of Public Administration Research and Theory, 3, 393-415.

Meier, K. J., Wrinkle, R. D., \& Polinard, J. L. (1999). Representative bureaucracy and distributional equity: Addressing the hard question. Journal of Politics, 61, 1025-39.

Neuman, W. R., Marcus, G. E., Crigler, A., \& MacKuen, M. (2007). The Affect Effect: Dynamics of Emotion in Political Thinking and Behavior. Chicago: University of Chicago Press.

Nørgaard, A. S. (1996). Rediscovering reasonable rationality in institutional analysis. European Journal of Political Research, 29, 31-57.

Ozer, D. J., \& Benet-Martínez, V. (2006). Personality and the prediction of consequential outcomes. Annual Review of Psychology, 57, 401-421.

Percy, S. L. (1984). Citizen Participation in the Coproduction of Urban Services. Urban Affairs Review, 19, 431-446.

Perry, J. L., Hondeghem, A., \& Recascino Wise, L. (2010). Revisiting the Motivational Bases of Public Service: Twenty Years of Research and an Agenda for the Future. Public Administration Review, 70, 68190.

Perry , J. L., \& Vandenabeele, W. (2015). Public Service Motivation Research: Achievements, Challenges, and
Future Directions. Public Administration Review, 75 692-99.

Petersen, M. B. (2015). Evolutionary Political Psychology: On the Origin and Structure of Heuristics and Biases in Politics. Political Psychology, 36, 45-78.

Redlawsk, D. P., Civettini, A. J., \& Emmerson, K. M. (2010). The affective tipping point: Do motivated reasoners ever "get it"? Political Psychology, 31, 563593.

Riccucci, N. M. , Van Ryzin, G. G., \& Li, H. (2016). Representative Bureaucracy and the Willingness to Coproduce: An Experimental Study. Public Administration Review, 76, 121-130.

Roberts, B. W., \& DelVecchio, W. F. (2000). The Rank-Order Consistency of Personality Traits from Childhood to Old Age: A Quantitative Review of Longitudinal Studies. Psychological Bulletin, 126, 3-25.

Rothstein, B. (1998). Just Institutions Matter: The Moral and Political Logic of the Universal Welfare State. Cambridge: Cambridge University Press.

Schwarz, N. (2000) Emotion, cognition, and decision making, Cognition and Emotion, 14, 433-440.

Simon, H. A. (1976 [1947]). Administrative Behavior: A Study of Decision-Making Processes in Administrative Organizations. $3^{\text {rd }}$ Edition. New York: The Free Press.

Shleifer, A. (2012). Psychologists at the Gate: A Review of Daniel Kahneman's Thinking, Fast and Slow. Journal of Economic Literature, 50, 1-12.

Stanovich, K. E., \& West, R. F. (2000). Individual Differences in Reasoning, Implications for the Rationality Debate? Behavioral and Brain Sciences, 23, 645-65.

Taber, C. S., \& Lodge, M. (2016). The illusion of choice in democratic politics: The unconscious impact of motivated political reasoning. Political Psychology, 37, 61-85.

Tajfel, H. (1981). Human Groups and Social Categories. Cambridge: Cambridge University Press.

Theobald, N. A., \& Haider-Markel, D. P. (2009). Race, Bureaucracy, and Symbolic Representation: Interactions between Citizens and Police. Journal of Public Administration Research and Theory, 19, 409-426.

Thomsen, M. K., \& Jakobsen, M. (2015). Influencing Citizen Coproduction by Sending Encouragement and Advice: A Field Experiment. International Public Management Journal, 18, 286-303.

Tummers, L., \& Knies, E. (2016). Measuring public leadership: Developing scales for four key public leadership roles. Public Administration, 94, 433-451.

Tversky, A., \& Kahneman, D. (1974). Judgment under uncertainty: Heuristics and biases. Science, 185, 11241131.

van Eijk, C. J. A. \& Steen, T. P. S. (2014). Why People Co-produce: Analysing Ctizens' Perceptions on CoPlanning Engagement in Health Care Services. Public Management Review, 16, 358-382. 
van Witteloostuijn, A., Esteve, M., \& Boyne, G.

(2017). Public Sector Motivation ad fonts: Personality Traits as Antecedents of the Motivation to Serve the Public Interest. Journal of Public Administration Research and Theory, 27, 20-35.

Weber, M. (1920). The theory of social and economic organization. New York: Oxford University Press.

Wright, B. E. (2015). The Science of Public Administration: Problems, Presumptions, Progress, and Possibilities. Public Administration Review, 75, 795-805. 